СТУДИЈЕ И РАСПРАВЕ

$\begin{array}{lr}\text { Стана Ристић } & \text { УДК 811.163.41'373 } \\ \text { Институт за српски језик САНу } & \text { https://doi.org/10.18485/slavistika.2018.22.2.1 } \\ \text { Београд, Србија } & \text { оригинални научни рад } \\ \text { stana.ristic@isj.sanu.ac.rs } & \text { примљено 14.02.2018. } \\ \text { Ивана Лазић-Коњик } & \text { прихваћено за штампу 04.10.2018. }\end{array}$

Ивана Лазић-Коњик прихваћено за штампу 04.10.2018.

Институт за српски језик САНУ

Београд, Србија

ivana.konjik@gmail.com

\title{
АСОЦИЈАТИВНО ПОљЕ „ПОРОДИЦА” У СРПСКОМ ЈЕЗИКУ*
}

У овом раду, који представља део нашег обимног истраживања по методологији Лублинске етнолингвистичке школе, анализираће се асоцијативно поље језичке слике српске породице на основу асоцијативног поља назива лексеме породица, њених кохипонима и деривата, на материјалу Асочијативног речника и Обратног асочијативног речника српског језика, с циљем издвајања најзначајнијих домена из њихових асоцијативних поља у виду центра, ближе, даље и крајње периферије.

Кључне речи: концепт, стереотип, језичка слика, породица, асоцијативно поље, домени / аспекти, етнолингвистика, српски језик.

The article reconstructs the associative field of the linguistic view of the Serbian FAMILY (PORODI$\mathrm{CA}$ ) on the basis of the associative field of the lexeme family (porodica), its cohyponyms and derivatives, drawing on material from the Associative Dictionary and the Reverse Association Dictionary of the Serbian language, in order to isolate the most important domains from their associative fields in the form of a center, proximate, further and distant peripheries.

Key words: concept, stereotype, linguistic view, family, associative field, domains / aspects, ethnolinguistics, Serbian language.

\section{Увод}

У вези са обимним истраживањем феномена који се односе на породицу у српском језику и култури за потребе Аксиолошког лексикона Словена и њихових суседа ${ }^{1}$ у овом раду представићемо језичку слику српске породице на асоцијативном материјалу (на материјалу Асоиијативног речника и Обратног асоцијативног речника српског језика) и то на основу асоцијативног поља назива лексеме породица, њених кохипонима и деривата, с циљем издвајања најзначајнијих домена из њихових асоцијативних поља у виду центра, ближе, даље и крајње периферије. Истраживање је рађено по методологије Лублинске етно-

* Рад је настао у оквиру пројеката МПНТР 178009 „Лингвистичка истраживања савременог српског књижевног језика и израда Речника српскохрватског књижевног и народног језика САНУ” и међуакадемисјког пројекта ИСЈ САНУ и СИ ПАН „Кључни концепти српске и пољске аксиосфере на словенском плану".

${ }^{1}$ Аксиолошки лексикон Словена и юихових суседа (Leksykon aksjologiczny Stowian i ich sąsiadów) чији је идејни творац и главни уредник проф. Јежи Бартмињски, резултат je рада већег броја лингвиста из различитих земаља на међународном пројекту EUROJOS којим такође руководи проф. Бартмињски. До сада су објављена три тома овог Лексикона: Дом (2015), Рад (2016) и Част (2017), у штампи се налазе још два: о Европи и слободи, а планирано је да се израде и томови о породици, здрављу, души, домовини, народу, патриотизму, демократији, солидарности, правди и толеранцији. 
лингвистичке школе која се развија под руководством проф. Јежија Бартмињског, по којој и подаци асоцијативног поља, заједно са анкетним, системским и текстуалним подацима (C-A-T), представљају релевантан језички материјал за реконструкцију језичке слике неког појма, односно начина концептуализације појма од стране говорника датог језика.

Погодност материјала из асоцијативних речника за етнолингвистичка и лингвокултуролошка истраживања, као и за реконструкцију концепата и стереотипа, показана је у великом броју србистичких и славистичких радова. Када су у питању резултати у домену концепта / стереотипа породицА, у србистици најобимније и најисцрпније истраживање урадила је Марија Стефановић (2012). Ова ауторка је, поред осталог, показала да статистичка обрада резултата, добијених анализом асоцијативних поља назива чланова уже и шире породице, даје егзактне податке на основу којих се може анализирати асоцијативно поље (даље АП) језичке слике породице са центром, ближом, даљом и крајњом периферијом, а самим тим и одредити важност и стабилност одређене когнитивне особине на основу припадности неком од наведених делова поља. На овај начин отвара се могућност за упоређивање концепата/стереотипа како између два или више различитих језика (генетски сродних и несродних), тако и унутар једног језика у смислу упоређивања резултата добијених анализом различитих материјала по хронолошким, жанровским и другим релевантним параметрима.

С обзиром на то да је у поменутом раду језичка слика породице рађена на поредбеном плану руског и српског језика, на основу асоцијативних поља лексема које означавају чланове уже и шире породице, на материјалу 14 асоцијативних поља, 8 руских и 6 српских, ми ћемо настојати да реконструишемо језичку слику српске породице на основу АП самог назива концепта, лексеме породица, њених кохипонима и деривата на материјалу $\mathrm{APCJ}^{2}$ и ОАРCJ. У APCJ као стимулус није дата лексема породииа, него само придев породични и именица родбина, па ћемо најпре навести податке асоцијативних поља наведених стимулуса.

\section{АП стимулУСА ,ПОРОДични"}

породични: ручак 114, човек, живот 73, скуп 50, кућни, људи, пријатељ, проблеми 17, фамилијарни, односи 16 , мир 15 , кућа 14, дом, заједнички 10 , топлина 9, албум, фамилијаран, круг, однос, породица, сто, топао 8 , љубав, проблем, сладолед, топло 6 , срећа 5 , ауто, мама, отац, празник, састанак, сукоб, топли 4, блиски, Божић, излет, пријатељи, родбински, срећни, топлота 3, брак, брижан, буџет, дан, договор, хармонија, идилични, кутак, лични, људски, најлепше, накит, наш, новац, обичај, огњиште, пас, припадност, род, рођени, сат, сигурност, традиција, вечера,

${ }^{2}$ Асоиијативни речник српског језика (АРСЈ) је урађен на основу материјала добијеног анкетирањем 800 испитаника, младе гимназијске и факултетске популације од 18 до 25 година у периоду 2002. и 2003. године. Издвојене најзначајније домене породице из ових асоцијативних поља упоредићемо (у посебном раду) са најзначајнијим доменима добијеним у одговорима на више питања која су се односила на различите аспекте породице, добијених анкетирањем 100 испитаника истог типа популације у периоду 2016. - 2017. године, значи у временском размаку око 14 година, са циљем да проверимо да ли је дошло до битнијих промена у концептуализацији породице код говорника савременог српског језика. 
заједно 2, адвокат, аутомобил, близак, бољи живот, боравак, брат, брижни, будућност, целокупни, чин, члан, човјек, чврсти темељи, ћуп, деца, добар, добро осећање, добростојећи, договори, домаћин, драг, друштвени, државни, дух, фамилија, фамилијарни човек, фамилијарно, филм, фото-албум, фотографије, глуп, хармоничан, хармоника, хотел, иметак, инвентар, јак, кашика, комшијски, комуникативан, корен, кравата, кретен, кућеван, ланац, лекар, лепо, лепо васпитан, љубавни, мама и тата, мамин-татин, мој, мужевни, надање, најбољи, намештај, нема, нереди, независност, обични, одан, окуп, опуштено, ослонац, паковање, папуче, патријархат, пажљив, породични, посао, пожртвован, праг, прави, прек, пријатни, присни, приватни, приватност, привржен, рачуни, радни, радно, распад, расуло, разговор, размажен, родитељи, родитељски, ручак недељом, ручак сто, ручак традиција, сако, савет, сигуран, симпатично, слога, смех, стални, стан, столица, сукоби, свађа, свакодневно, све најдраже, сви, својствен, тата, темељни, толерантни, традиционални, трпеза, у ланцима, учтив, угледан, унутрашњи, велики, веран породици, вољени, заједница, затворен, завезани, збор, зналац, зрео, жена 1; 800 $(223,540,90)+192+22+126$.

У АП „породични” од 800 испитаника њих 192 дало је различите одговоре, чија је учесталост / број појављивања назначена бројевима иза истог одговоpa, 126 означава број појединачних одговора а 22 испитаника нису дали никакав одговор.

\section{АП СТИМУлУСА ,РОДБИНА"}

родбина: породица 56, фамилија 41, тетка 32 , пријатељи 30 , рођаци 29 , љубав 21, село 20, досада 17, слава, весеље 13, крв 12, скуп, свадба 11, веза 10, блискост, брат, људи, велика 9, ближа, род 8, баба, баба и деда, посета, рођендан, сестра, срећа, ујак 7, бака, далеко, кућа, много, рођак, стриц, 6, ручак, славље, смор 5, ближњи, далека, гужва, мама, многобројна, окупљање, поклони, повезаност, сигурност, свађа, топлина, ујна 4, близина, даља, дружење, гости, мноштво, моја, паре, подршка, празник, радост, родбина, сродство, тетке, 3, бабе, блиско, Босна, бука, даљина, досадна, досадно, гомила, и пријатељи, лепа, најближа, најближи, напаст, напор, ништа, обавеза, обавезе, помоћ, посете, поверење, пуна кућа, пуно, сахрана, састанак, скупови, смарачи, сморови, сусрет, својта, утеха, уточиште, велико, задовољство, заједница, жива 2, бабе и деде, бабе и тетке, бака и деда, баке, безбрижност, Бијело Поље, битно, блиска, блиски, блиски људи, богата, богатство, Божић, браћа, број, бројна, Будва, Чачак, Чикаго, давежи, дављење, дебили, деда, долази, досадне будале, драги, драги људи, дрво, држава, Ђурђевдан, формалности, фудбал, галама, гњавежи, град, Хрватска, Италија, Ивањица, издајица, Израел, је ту, кецеља, кеш, кева, ко ће попамтити, кокошке, количина, круг, крв није вода, крвно сродство, кудеља, лаж, лажљива, лепота, лоза, луђаци, љубомора, магловито, мајке, Македонија, мама и тата, маса, маторци, миловање, много људи, моји, море, мржња, наметнута, наслеђе, не бираш, не ваља, недеља, недостатак, неискреност, немогућност из- 
бора, неповезаност, непознати, непријатељ, незаинтересован, Нова година, огромна, огромно, окуп, оптерећење, осмех, остали, отуђеност, паприка, песма, поклон, порекло, породично стабло, потребан је, потребно, познаник, празници, празно, превише, презиме, прича, причати, пријатељ, пријатељство, пријатност, Пријепоље, присност, проблем, пут, рад, раја, Рашка, разговор, решење, родитељи, рођака, роштиљ, С. Митровица, са села, сећање, сељаци, скуп људи, слова, сложна, сложност, сродност, сто, стрина, судбина, сумњиво, сва родбина, свастика, Свилајнац, свраб, Шабац, штекаре, теча, туђа, туђина, твоја, удаљеност, унутрашњост, уплакана, велики број, Војводина, волети, Задар, захвалност, закон, зближавање, здрави људи, зона сумрака $1 ; 800(164,442,44)$ $+248+23+152$.

У АП „родбина” од 800 испитаника њих 248 дало је различите одговоре, чија је учесталост / број појављивања назначена бројевима иза истог одговора, 152 означава број појединачних одговора, а 23 испитаника нису дали никакав одговор.

\section{АНАЛИЗА РЕЗУЛТАТА АП СТИМУЛУСА „ПОРОДИЧНИ” И АП СТИМУЛУСА „РОДБИНА”}

Реакције на ове стимулусе на основу семантичке сличности њихових лексичких експонената груписаћемо у аспекте/домене на основу којих ћемо одредити когнитивне особине концепта породицА, при чему ћемо узимати у обзир све наведене реакције без обзира на учесталост појављивања, како бисмо на основу укупног броја реакција у оквиру сваког појединачног домена утврдили његово место у структури АП према припадности центру или периферији.

Резултате ћемо статистички обрадити и представити према методи Лублинске етнолингвистичке школе (изложене у JWP 2006). Одговоре / реакције на посматране стимулусе у АРCJ обрадићемо као минималне контексте, цитате, од којих сваки представља једну особину испитиваног појма. Укупан број цитата означава се латиничним словом W. Цитати сасвим блиског значења обједињавају се под надређени заједнички метаизраз, дескриптор, који се обележава латиничним словом D. Дескриптор може обухватити од једног до више десетина цитата, па се уобичајено у анализи дескриптори наводе према фреквенцији. Виши степен категоризације представља обједињавање дескриптора у домене / аспекте према некој општој заједничкој карактеристици (листу аспеката, која није коначна, в. у JWP 2006: 40-41).

\section{АРСЈ: АП стимулуса ,породични"}

Домени у АП стимулуса ,породични” (W=778):

D 1 социјални домен (S) 518 (66,58\%)

a) опште карактеристике: човек 73 , живот 73 , људи 17 , односи 16 , круг 8 , однос 8 , припадност 2 , члан 1 , човјек 1 , чин 1 , фамилијарни човек 1 , жена 1 , родитељски 1 , унутрашњи 1, затворен $1=205$ (26,35\%)

б) окупљање: породични ручак 114 , скуп 50 , празник 4 , састанак 4 , излет 3 , Божић 3 , дан 2, вечера 2 , боравак 1 , ручак недељом 1 , трпеза 1 , ручак традиција 1, окуп 1 , сви 1 , збор $1=189(24,29 \%)$ 
в) чланови породице: мама 4, отац 4, мама и тата 1 , мамин-татин 1 , брат 1 , деца 1 , родитељи 1 , тата $1=14(1,80 \%)$

г) творбено-семантички аспекти 21 (2,70\%):

$\Gamma_{1)}$ мотивна реч: породица $8=8$

$\Gamma_{2}$ ) кохипоними породице: род 2, огњиште 2, људски 2, наш 2, заједница 1 , фамилија 1, праг 1, државни 1, комшијски $1=13$

д) парадигматски односи 67 (8,61\%)

$д_{1}$ ) синоними: кућни 17, фамилијарни 16 , заједнички 10 , фамилијаран 8 , родбински 3 , рођени 2, заједно 2, друштвени 1 , кућеван $1=60$

$д_{2}$ ) антоними / опозити: лични 2, приватни 1, приватност 1, независност 1 , мој $1=6$

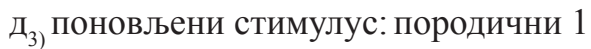

ђ) брачни аспект: брак $2=2(0,26 \%)$

е) сродност по души: пријатељ 17, пријатељи $3=20$ (2,57\%)

Укупно $=518$

\section{D психолошки домен (Р) 133 (17,09\%)}

a) позитивни: мир 15 , топлина 9, топао 8, топло 6 , топли 4 , топлота 3 , блиски 3 , идилични 2, најлепше 2, договор 2, хармонија 2, сигурност 2, присни 1 , договори 1 , ослонац 1 , привржен 1 , сигуран 1 , близак 1 , пажљив 1 , пожртвован 1 , веран породици 1 , толерантни 1 , разговор 1 , слога 1 , смех 1 , савет 1 , хармоничан 1 , бољи живот 1 , чврсти темељи 1 , будућност 1 , добар 1 , драг 1 , дух 1 , фамилијарно 1, комуникативан 1 , лепо 1, надање 1 , најбољи 1 , одан 1 , опуштено 1 , пријатни 1 , размажен 1 , симпатично 1 , прави 1 , радни 1 , радно 1 , учтив 1 $=93(11,95 \%)$

б) негативни: проблеми 17, проблем 6, сукоб 4, брижан 2, нереди 1 , расуло 1 , сукоби 1 , свађа 1 , брижни 1 , распад $1=35$ (4,5\%)

в) особине чланова породице: прек 1 , зналац 1 , зрео $1=3(0,38 \%)$

г) неутрални: својствен 1, обични $1=2(0,26 \%)$

Укупно $=133$

D физички домен (F) 76 (9,77\%)

a) имовина / колекција ствари: кућа 14 , дом 10 , сто 8 , ауто 4, новац 2, накит 2 , пас 2 , сат 2 , иметак 1 , стан 1 , аутомобил 1 , ћуп $1^{3}$, филм 1 , фото-албум 1 , фотографије 1 , хармоника 1 , хотел 1 , инвентар 1 , кашика 1 , кравата 1 , намештај 1, папуче 1 , сако 1 , столица $1=60(7,70 \%)$

б) храна: сладолед $6(0,77 \%)$

в) колекција услуга: адвокат 1 , лекар $1=2(0,26 \%)$

г) колекција радњи: паковање 1 , ручак сто $1=2(0,26 \%)$

д) особине чланова породице: јак 1 , мужевни $1=2(0,26 \%)$

ђ) временски: стални 1, свакодневно $1=2(0,26 \%)$

${ }^{3}$ Прецедент на основу серије „Породично благо“. 
е) квантитативни: велики 1 , целокупни $1=2(0,26 \%)$

Укупно $=76$

$\mathbf{D}_{4}$ аксиолошки домен 22 (2,83\%)

a) позитивни: албум 8 , традиција 3 , обичај 2 , домаћин 1 , патријархат 1 , лепо васпитан 1 , традиционални 1 , угледан $1=18(2,31 \%)$

б) негативни: у ланцима 1 , завезани 1 , глуп 1 , кретен $1=4(0,52 \%)$

Укупно $=22$

D $\mathbf{5}$ емотивни домен 18 (2,31\%)

љубав 6 , срећа 5 , срећни 3 , љубавни 1 , вољени 1 , све најдраже 1 , добро осећање $1=18$

D

кутак 2 , буџет 2 , темељни 1 , добростојећи 1 , посао 1 , рачуни $1=8$

Укупно $=8$

D $_{7}$ егзистенцијални домен (В) 1 (0,13\%)

нема $1=1$

$\mathbf{D}_{8}$ генеалошки домен $=2(0,26 \%)$

корен 1 , ланац $1=2$

\section{АРСЈ: АП СТИМУЛУСА ,РОдБинА"}

Домени у АП стимулуса ,родбина” (W=777):

$\mathbf{D}_{1}$ социјални домен (S) 458 (58,94\%)

a) опште одређење и дефиниције родбине: скуп 11 , веза 10 , људи 9 , ближа 8 , далека 4 , даља 3 , моја 3 , најближа 2, најближи 2 , не бираш 1 , судбина 1 , закон 1 , богатство 1 , остали 1 , круг 1 , магловито 1 , твоја 1 , унутрашњост 1 , мајке $1=$ $62(7,98 \%)$

б) кохипоними: породица 56 , фамилија 41 , рођаци 29 , род 8 , ближњи 4 , сродство 3 , својта 2 , заједница 2 , крвно сродство 1 , лоза 1 , моји 1 , скуп људи 1 , сродност 1 , држава $1=151(19,43 \%)$

в) антоними / опозити: туђина 1 , туђа 1 , непријатељ $1=3(0,39 \%)$

г) поновљен стимулус: родбина $3=3(0,39 \%)$

д) чланови родбине: тетка 32 , брат 9, баба и деда 7 , баба и деца 7, сестра 7 , ујак 7 , бака 6 , рођак 6 , стриц 6 , мама 4 , ујна 4 , тетке 3 , бабе 2 , баке 1 , деда 1 , кева 1 , бабе и деде 1 , бабе и тетке 1 , бака и деда 1 , браћа 1 , мама и тата 1 , маторци 1 , родитељи 1 , рођака 1 , стрина 1 , сва родбина 1 , свастика 1 , теча $1=115(14.8 \%)$

ђ) окупљање: слава 13 , весеље 13 , свадба 11 , посета 7 , рођендан 7 , ручак 5 , славље 5 , окупљање 4 , гости 3 , празник 3 , сусрет 2 , посете 2 , сахрана 2 , састанак 2 , скупови 2 , Нова година 1 , Божић 1 , долази 1 , празници 1 , Ђурђевдан 1 , море 1 , недеља 1 , окуп $1=89(11,45 \%)$

е) сродство по души: пријатељи 30 , и пријатељи 2 , познаник 1 , пријатељ 1 , paja $1=35(4,5 \%)$

Укупно $=458$

Славистика XXII/2 (2018) 
D 2 психолошки домен (Р) 120 (15,44\%)

а) позитивни: блискост 9, повезаност 4, сигурност 4, топлина 4, дружење 3 , подршка 3, блиско 2, помоћ 2, поверење 2, утеха 2, уточиште 2, задовољство 2, блиска 1 , блиски људи 1 , драги људи 1 , миловање 1 , пријатељство 1 , присност 1 , сећање 1 , сложна 1, волети 1, зближавање 1 , уплакана 1, велико 1, задовољство 1 , безбрижност 1 , блиски 1 , осмех 1, песма 1, потребан је 1 , потребно 1, прича 1 , причати 1 , пријатност 1 , решење 1 , слова 1 , сложност 1 , разговор 1 , захвалност 1 , битно $1=67(8,62 \%)$

б) негативни: свађа 4, бука 2, досадно 2, обавезе 2, досадна 2, напаст 2, напор 2, обавеза 2, наметнута 1, не ваља 1, недостатак 1, неискреност 1, немогућност избора 1, неповезаност 1, непознати 1, незаинтересован 1, оптерећење 1 , отуђеност 1 , формалности 1 , проблем 1 , ко ће попамтити 1 , удаљеност 1 , зона сумрака 1 , дављење 1 , галама 1 , празно 1 , сумњиво 1 , лаж $1=38$ (4,89\%)

в) особина чланова породице: смарачи 2 , сморови 2 , издајица 1 , лажљива 1 , луђаци 1 , штекаре 1 , кокошке 1 , давежи 1 , дебили 1 , досадне будале 1 , гњавежи 1 , свраб $1=14(1,8 \%)$

г) интересовање: фудбал $1=1(0,13 \%)$

Укупно $=120$

\section{D физички домен (F) 120 (15,44\%)}

а) лоцираност: село 20, далеко 6, кућа 6, близина 3, Босна 2, даљина 2, Бијело Поље 1, Будва 1, Чачак 1, Чикаго 1, је ту 1, град 1, Хрватска 1, Италија 1, Ивањица 1, Израел 1, Македонија 1, Пријепоље 1, пут 1, Рашка 1, С. Митровица 1, Свилајнац 1, Шабац 1 , Војводина 1 , Задар 1 , са села 1 , сељаци $1=60(7,72 \%)$

б) квантитативни: велика 9, много 6, гужва 4, многобројна 4, мноштво 3, гомила 2, пуно 2, пуна кућа 2, бројна 1, богата 1 , много људи 1 , огромна 1 , превише 1 , велики број 1, број 1, количина 1 , маса 1 , огромно $1=42(5,4 \%)$

в) колекција ствари / имовина: поклони 4, паре 3 , поклон 1, кецеља 1, кудеља 1, сто 1 , кеш $1=12(1,54 \%)$

г) храна: паприка 1 , роштиљ $1=2(0,26 \%)$

д) перцептивни: лепа 2 лепота $1=3(0,39 \%)$

ђ) здравље: здрави људи $1=1(0,13 \%)$

Укупно $=120$

$\mathbf{D}_{4}$ емотивни домен 56 (7,2\%)

а) позитивни: љубав 21, срећа 7, радост 3, драги $1=32(4,11 \%)$

б) негативни: досада 17, смор 5, мржња 1, љубомора $1=24$ (3,09\%)

Укупно $=56$

D 5 генеалошки домен 18 (2,33\%)

крв 12, крв није вода 1, наслеђе 1, порекло 1, породично стабло 1, презиме 1 , дрво $1=18$

D

жива 2, ништа 2, рад $1=5$ 
У пољу стимулуса „родбина” у социјалном домену међу реакцијама са значењем чланова родбине од 102 реакције истичу се по броју шири чланови родбине / породице: тетка 35 (тетка 32, тетке 3), баба 20 (баба 7, баба и дейа 7, бака 6), ујак 7, стрии 6, рођак 6 и са по једним појављивање: ујна, рођака, стрина, свастика, теча ${ }^{4}$ а од ужих чланова са већим бројем појављивања: сестра 7, мама 4 и са по једним појвљивањем: браћа, мама и тата, маторичи, родитељи.

\section{ОАРС}

породииа: родбина 56 , подршка 55 , дом 43 , слога 42 , рођаци 37 , родитељи 36 , отац 30 , порекло 29 , муж 23 , рођака 19 , кћерка 16 , кућни 13 , таст 12 , љубав 11 , огранак 11 , заједно 10 , сестра 9, снаха 9, тетка 9, зет 9, породични 8 , ташта 8 , унија 8 , мама 7 , моћна 7 , америчка 6 , глава 6 , срећа 6 , тата 6 , због губитка 6 , будућност 5 , рођени 5 , син 5 , темељ 5 , волети 5 , вољени 5 , забринутост 5 , круг 4 , крв 4 , љубављу 4 , нов 4 , патриотизам 4 , сина 4 , срећом 4 , живот 4 , богатство 3 , јединство 3 , мужеви 3 , радост 3 , за родитеље 3 , ближе 2 , чедо 2 , губици 2 , хлеб 2 , нежношћу 2 , част 1 , демократија 1 , дете 1 , добродушан 1 , драти се 1 , екологија 1 , фото 1 , гласно 1 , историја 1 , изнад 1 , ја 1 , Југославија 1 , југословенски 1 , кров 1 , моралан 1 , нежан 1 , огорченост, они 1 , после 1 , праг 1 , приход 1 , приватизација 1 , радник 1 , Равна гора 1 , родољуб 1 , Срби 1 , Србија 1 , свуда 1 , топао 1 , уједињени 1 , велик 1 , војник 1 , вољена 1 , вредност 1 , за 1, желели 1; $675+91$

Лексема породииа у ОАРСЈ јавља се као реакција 675 пута $(\mathrm{W}=675)$ на 91 стимулус односно у деведесет једном асоцијативном пољу од укупно 600 поља из АРСЈ.

Домени у АП реакције „породица”:

D

a) чланови породице: рођаци 37 , родитељи 36 , отац 30 , муж 23 , рођака 19 , кћерка 16 , таст 12 , сестра 9 , снаха 9 , тетка 9 , зет 9 , ташта 8 , мама 7 , тата 6 , син 5 , сина 4 , мужеви 3 , за родитеље 3 , чедо 2 , дете $1=248$

б) кохипоними: родбина 56 , дом 43 , огранак 11 , заједно 10 , унија $8=128$

в) опште карактеристике и дефиниција: рођени 5 , живот 4 , круг 4 , богатство 3 , јединство 3 , уједињени 1 ; темељ 5 , кров 1 , праг 1 , Срби 1 , Србија 1 , Југославија 1 , југословенски $1=31$

г) творбени аспекат: породични $8=8$

\footnotetext{
${ }^{4}$ Овај податак показује да млада популација говорника српског језика називе чланова шире породице не само да познаје него да их има у свом активном вокабулару, за разлику од младе популације у неким другим језицима, нпр. руском. У раду Дюзенли 2014, у коме је истраживање концепта породицА рађено на материјалу слободног асоцијативног теста на 13 стимулуса, родбинских назива, 100 руских и 70 кинеских носилаца језика младе популације, утврђено је да припадницима млађе руске генерације нису познати сви називи шире породице, „,родства по закону“, типа: снаха, зет, ташта, таст, свекар, свекрва за разлику од кинеске популације којима су ти називи били мање-више познати (нав. дело: 30-31).
} 
д) опозити: ја 1, они 1, америчка 6 (опозит према моја/српска и сл. породица) $=8$

ђ) улога / статус у породици: глава 6 , нов $4=10$

Укупно $=433$

D психолошки домен (Р) 125 (18,52\%)

a) позитивни: подршка 55 , слога 42 , моћна 7 , будућност 5 , срећом 4 , желели 1 , топао 1 , за 1 [породицу] $=116$

б) негативни: забринутост 5 , губици 2 , драти се 1 , огорченост $1=9$

Укупно $=125$

\section{D емотивни домен 39 (5,78\%)}

позитивни: љубав 11, срећа 6, волети 5, вољени 5, љубављу 4, нежношћу 2 , добродушан 1 , радост 3 , нежан 1 , вољена $1=39$

D генеалошки домен 33 (4,89\%)

порекло 29, крв $4=33$

D

a) месна лоцираност: кућни 13 , ближе 2 , изнад 1 , свуда $1=17$

б) временска лоцираност: после $1=1$

в) перцептивни: фото 1, гласно 1, велик $1=3$

D егзистенцијални домен (B) 13 (1,93\%)

a) општи: због губитка 6 , хлеб 2 , екологија $1=9$

б) радни / професионални: приход 1 , приватизација 1 , радник 1 , војник $1=4$

$\mathbf{D}_{7}$ аксиолошки домен 11 (1,63\%)

патриотизам 4, част 1 , демократија 1 , историја 1 , моралан 1 , Равна гора 1 , родољуб 1 , вредност $1=11$

Падежни облици лексеме породица, као и облици и синтагме њеног деривата породични, јављају се такође као реакције уз одређен бој стимулуса, па смо из ОАРСЈ анализирали и овакве случајеве, ради употпуњености језичке слике појма поРодицА.

Најпре ћемо размотрити оне примере који се јављају као реакција уз више стимулуса. Такав пример је реакција генитивног облика породище који се јавља 43 пута (W=43) код 10 стимулуса: глава 16, због губитка 9, подршка 7, порекло 3 , огранак 2 , круг 1, остаци 1 , част 1, грб 1, историја 1, стваралаштво1.

Из овог невеликог АП можемо издвојити следеће домене концепта / стереотипа ПородицА:

D $_{1}$ социјални домен (S) 19

a) опште карактеристике: огранак 2 , круг $1=3$

б) улога у породици: глава $16=16$

D егзистенцијални домен (B) 9

због губитка $9=9$ 
D психолошки домен (P) 7

подршка 7

$D_{4}$ аксиолошки домен 4

част 1 , грб 1, историја 1 , стваралаштво 1

$D_{5}$ генеалошки домен 3

порекло 3

D $_{6}$ физички домен (F) 1

остаци 1

Затим имамо пример реакције породично стабло која се јавља 10 пута $(\mathrm{W}=10)$ као реакција на 4 стимулуса: порекло 7 , огранак 1 , родбина 1 , рођака 1 . Издвајају се два домена:

\section{$\mathrm{D}_{1}$ генеалошки домен 7}

порекло 7

\section{$\mathrm{D}_{2}$ социјални домен 3}

огранак 1 , родбина 1 , рођака 1

Остале случајеве реакција преформулисаћемо у граматичке спојеве и везе, и на основу њих издвојити још неке домене концепта породицА. Тако је реакцију у виду модела двеју речи „породица наследство” уз стимулус „крв” могуће трансформисти у исказ: Породично наследство одређује се на основу крви (крвне везе); реакцију и стимулус „породично” „порекло” у синтагму: породично порекло; „породична лоза” „сина” $\rightarrow$ Син има улогу да продужи породичну лозу / Породична лоза се продужава преко сина и сл. - генеалошки домен 3 ; парове реакција и стимулуса „породицу” „имати” $\rightarrow$ имати породииу; „Породичан” „кућни” $\rightarrow$ Породичан значи исто што и кућни; „породична вечера" „зет” $\rightarrow$ Зет је позван на породичну вечеру / Породичну вечеру организујемо због зета и сл.; „породичне везе” „зет” $\rightarrow$ Преко зета проширујемо породичне везе / У породичне везе убраја се и зет и сл.; „породични скуп” „рођаци” $\rightarrow$ Рођации чине/организују и сл. породични скуп социјални домен 5, „породицу” „волети” $\rightarrow$ Волим (соју) породицу; „породична” „срећан” $\rightarrow$ породична срећа; „породица расте” „нежношћу” $\rightarrow$ Гледам како породица расте с нежношћу - емотивни домен 3 ; „породици” „подршка” $\rightarrow$ подрика породици - психолошки домен 1 ; „породично васпитање” „неморалан” $\rightarrow$ Бити неморалан је ствар породичног васпитаға / Породично васпитање не толерише да се буде неморалан и сл. - аксиолошки домен 1.

Редослед домена наводимо обједињено по броју стимулуса уз које се „породица” (одн. облик генитива „породице”, контекстуална употребе речи „породица” и придева „породичан”) јавља као реакција (W=741 $(675+66))$ : социјални домен $460(433+27,62,07 \%)$, психолошки домен $133(125+8,17,95 \%)$, генеалошки домен $46(33+13,6,21 \%)$, емотивни домен $42(39+3,5,67 \%)$, физички домен $22(21+1,2,97 \%)$, егзистенцијални домен $22(13+9,2,97 \%)$ и аксиолошки домен $16(11+5,2,16 \%)$.

Славистика XXII/2 (2018) 


\section{ПРЕГЛЕД ДОМЕНА ПО АСОЦИЈАТИВНИМ ПОљИМА}

У пољу стимулуса породични редослед домена наводимо по броју реализованих реакција: социјални домен 518 (66,58\%), психолошки домен 133 (17,09\%), физички домен 76 (9,77\%) аксиолошки домен 22 (2.83\%), емотивни домен $18(2,31 \%)$, егзистенцијално-физички домен 8 (1,03\%), генеалошки домен $2(0,26 \%)$ и егзистенцијални домен $1(0,13 \%)$.

У пољу стимулуса родбина редослед домена наводимо по броју реализованих реакција: социјални домен 458 (58,94\%), психолошки домен 120 (15,44\%), физички домен 120 (15,44\%), емотивни домен 56 (7,2\%), генеалошки 18 (2,33\%) и егзистенцијални домен 5 ( $0,65 \%)$.

Редослед домена по броју стимулуса уз које се 'породица' јавља као реакција: социјални домен 460 (62,07\%), психолошки домен 133 (17,95\%), генеалошки домен 46 (6,21\%), емотивни домен 42 (5,67\%), физички домен 22 (2,97\%), егзистенцијални домен 22 (2,97\%) и аксиолошки домен 16 (2,16\%)

Укупан збир домена у сва три поља (W=2296 (778+777+741)), према доменима, изгледа овако (в. такође у табели):

$$
\begin{aligned}
& \mathbf{D}_{1} \text { социјални домен }=1436(62,54 \%) \\
& \mathbf{D}_{2} \text { психолошки домен }=386(16,81 \%) \\
& \mathbf{D}_{3} \text { физички домен }=218(9,5 \%) \\
& \mathbf{D}_{4} \text { емотивни домен }=116(5,05 \%)
\end{aligned}
$$

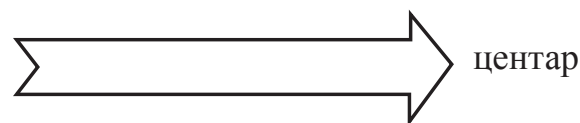

\begin{tabular}{|c|c|c|c|c|c|c|c|c|}
\hline АП пОРОДицА / D & $\mathrm{S}$ & $\mathrm{P}$ & $\mathrm{F}$ & емот. & ген. & акс. & B & B-F \\
\hline број цитата (према доменима) & 1436 & 386 & 218 & 116 & 66 & 38 & 28 & 8 \\
\hline$\%$ & 62,54 & 16,81 & 9,5 & 5,05 & 2,87 & 1,66 & 1,22 & 0,35 \\
\hline стимулус „породични” & 518 & 133 & 76 & 18 & 2 & 22 & 1 & 8 \\
\hline стимулус „родбина” & 458 & 120 & 120 & 56 & 18 & - & 5 & - \\
\hline реакција „породица” и сл. & 460 & 133 & 22 & 42 & 46 & 16 & 22 & - \\
\hline & центар & \multicolumn{3}{|c|}{ ближа периферија } & \multicolumn{3}{|c|}{ даља периферија } & $\begin{array}{l}\text { крајња } \\
\text { периф. }\end{array}$ \\
\hline
\end{tabular}

$$
\begin{aligned}
& \mathbf{D}_{5} \text { генеалошки домен }=66(2,87 \%) \\
& \mathbf{D}_{6} \text { аксиолошки домен }=38(1,66 \%) \\
& \mathbf{D}_{7} \text { егзистенцијални домен }=28(1,22 \%)
\end{aligned}
$$

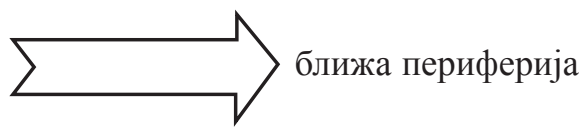

$\mathbf{D}_{\mathbf{8}}$ егзистенцијално-физички домен $\left.=8(0,35 \%) \sum\right\rangle$ крајња периферија

Табела: Укупан збир домена у сва три поља $(W=2296)$, према доменима 


\section{ЗАКљУЧАК}

На основу анализе асоцијативних поља стимулуса „породични” и „родбина" и реакције „породица” издвојени су типови реакција по доменима / аспектима који су битни за реконструисање концепта породицА и за функционисање породице у српском језику. Као најрелевантнији показали су се социјални и психолошки домени са високим бројним вредностима реакција, с тим што социјални домен организује центар у сва три појединачна поља, и наравно, у укупном збиру обједињеног АП језичке слике породице. Осим њих, високу вредност, неједнако у сва три поља, показују и емотивни, аксиолошки, егзистенцијални, физички и генеалошки домени, који зависно од поља могу да се нађу у ближој, даљој или крајњој периферији.

Пошто овај рад предствља део нашег обимног истраживања концепта породицА у српском језику, опширнију анализу добијених квантитативних резултата асоцијативног поља српске породице, као и лингвокултуролошке коментаре ових резултата у смислу њихове релевантности за реконструкцију / концептуализацију језичке слике овог појма у српском језику, биће предствљни у коауторској монографији, чија је израда у току.

\section{Цитирана литература}

Дюзенли, М. В., Ли Цзянь. «Ассоциативные репрезентации концепта „семья“ в сознании современной российской и китайской молодежи», Материалы ежегодной конференции, 1-2 июня, 2014, 29-34. <http://elar.urfu.ru/bitstre am/10995/36871/1/978-5-91256-252-5_2014_05.pdf> 13.2.2018.

Стефановић, Марија. Језичка слика породице у руском и српском језику. Нови Сад: Филозофски факултет у Новом Саду, 2012.

JWP 2006: Jerzy Bartmiński, (red.). Język. Wartości. Polityka. Zmiany rozumienia nazw wartości w okresie transformacji ustrojowej w Polsce. Raport z badań empirycznych. Lublin: Wydawnictwo UMCS, 2006.

\section{Извори}

APCJ: Пипер, Предраг, Рајна Драгићевић, Марија Стефановић. Асоцијативни речник српског језика. I део: од стимулуса ка реакцији. Београд: Београдска књига, Службени лист СЦГ, Филолошки факултет, 2005.

OAPCJ: Драгићевић, Рајна, Предраг Пипер, Марија Стефановић. Обратни асоцијативни речник српског језика. Од реакције ка стимулусу. Београд: Београдска књига, 2011. 
Стана Ристич, Ивана Лазич-Коник

АССОЦИАТИВНОЕ ПОЛЕ „ПОРОДИЦА” („СЕМЬЯ”) В СЕРБСКОМ ЯЗЫКЕ

\section{Резюме}

В статье проведен анализ ассоциативного поля языковой картины сербской сЕмьи на основе ассоциативного поля лексемы породица («семья»), ее гипонимов и дериватов, на материале «Ассоциативного словаря» и «Обратного ассоциативнаго словаря» сербского языка. На основе когнитивного анализа минимальных контекстов, полученных из ответов или стимулов из указанных ассоциативных полей, были идентифицированы соответствующие дескрипторы, через которые в дальнейшей категоризации были определены аспекты концепта / стереотипа сЕмья в указанных ассоциативных полях и в объединенном ассоциативном поле. Статистический анализ численных значений дескрипторов в каждом отдельном аспекте показал, что центром объединенного ассоциативного поля является социальный аспект, близкую периферию составляют психический, физический и эмоциональний аспекты, дальнюю периферию - генеалогический, аксиологический и экзистенциальний аспекты, а крайняя периферия представлена экзистенциально-физическим аспектом.

Ключевые слова: концепт, стереотип, языковая картина, семья (породица), ассоциативное поле, аспект, этнолингвистика, сербский язык. 